\title{
ECONOMIC ANALYSIS OF BROILER PRODUCTION IN ENVIRONMENT CONTROLLED HOUSES IN DISTRICT FAISALABAD
}

\author{
Ahmad Ullah Arslan' ${ }^{1}$, Muhammad Khalid Bashir ${ }^{1}$, Muhammad Farooq Khalid ${ }^{1}$, Muhammad \\ Auon$^{1}$, Umar Farooq1', Muhammad Ashraf ${ }^{1}$, Shafaq Shakeel ${ }^{2}$ and Shahid-ur-Rehman 1,* \\ ${ }^{1}$ University of Agriculture, Faisalabad, Sub Campus Toba Tek Singh-36050, Pakistan; \\ ${ }^{2}$ Department of Zoology, Government College Women University, Sialkot, Pakistan. \\ "Corresponding author's e-mail: shahidurrehman@uaf.edu.pk
}

\begin{abstract}
This study was planned to assess the profitability of broiler farming in environment controlled houses in and around Faisalabad. Price of chicks, cost of labor, feed, building, flock, medicine, vaccination, disinfection on the profit of the broiler producer were investigated. A questionnaire was developed to collect required information and data were collected through formal interviews by visiting, 35 broiler flocks raised in environment control houses. In the study area average flock size was 29210 birds with $471 \times 46.91$ average dimensions having a stocking density of 0.74 square feet and average cost of day old chick amounted to Rs. 45 (study was carried out during the second quarter of 2014) which accounted 33.30\% of total cost. Cost of finisher feed (Rs. 53.50) established the maximum share of the total cost, accounting for $44.10 \%$ while cost of starter feed contributed $10.21 \%$ of total cost. Cost of vaccination and medication was $3.11 \%$ while the cost of labor accounted for $4.00 \%$ of total cost. Further stuffs such as repair and management cost, fuel, bills, feeders, drinkers and litter cost contributed $<2 \%$ to total cost of production. The average net return gained by the farmers were Rs. 65000 per flock of 30000 birds. Economic indicators values viz. rate of returns on investment (\%) 33.50, rate of return on variable cost (\%) 140, rate of return on fixed cost (\%) 430 with a capital turnover of about 1.50 and profitability index of about 0.30 .

Keywords: Poultry, profitability, meat production, housing technology, feed efficiency, vaccination.
\end{abstract}

\section{INTRODUCTION}

Poultry industry has become the second largest industry of Pakistan. The share of poultry meat is $30 \%$ in total meat production of Pakistan (GOP, 2015-16). Modern broiler industries are much described by mass broiler production with a high turnover of investment but low profit per broiler. Success in business is mostly determined by the skills of business persons to control the cost of production. For fine tuning of the poultry business farmers especially with reference to profitability broiler farmers/researchers need to assess the contribution of each management factor for competing in international markets where the profit margins are decreasing (Ceveger and Yalcin, 2003).

Increase in production efficiency of broiler farms is mainly due to advancement in equipment and housing technology. However, Liang et al., (2013) enumerated that housing and equipment changes are not the only factors behind the increased production efficiency of the broiler industry. Broiler strains' genetic improvement for growth rate, feed efficiency and liveability are other factors that augment the increased efficiency of broilers. After the involvement of yearly strain developments and related health and nutritional programs are considered, modern broiler housing with better environmental-control ability is significant for enhancing weight gain, liveability and feed conversion (Liang et al., 2013).

In Pakistan, broilers are generally reared in open-sided houses. In mild climates these open sided houses may not cause major problem for broiler farming. On the other hand, it would become difficult in open-sided houses when the environmental conditions are harsh in summer or winter seasons. Severe production losses may occur resulting in economic losses if an optimum environment is not confirmed within the houses (Zahir-ud-Din et al., 2005).

There are no hard and fast rules for increasing the profit from broiler production. Maximum profit can be attained by receiving a peak margin over the variable cost. There are two traditions to increase the profit margin. Firstly, profits need to be increased, whichever through reaching advanced levels of production or through marketing the product at a higher price. Secondly, the variable cost should be decreased as much as possible (Samarakoon and Samarasinghe, 2012).

In this changing scenario broiler farmers are shifting to controlled environment housing system and automated feed and water equipment etc. there is a dire need to optimize the inputs by fine tuning the practices and operations to optimize outputs for longer term survival. A lot of work is required to re-establish the already established practices especially with reference to changing production system for the improvement of Pakistan poultry industry. The present study was planned 
to assess the profitability structure for the farmers in and around Faisalabad.

\section{MATERIALS AND METHODS}

The study was focused to Faisalabad district (Punjab) and was based upon the collection of primary data through a survey during second quarter of 2014 from 35 flocks which were reared in environment control houses. The list of poultry farms located in Faisalabad district was obtained from Pakistan Poultry Association (PPA) office in Faisalabad. Environment control house poultry farmers were selected through simple random sampling. The farmers were personally surveyed and data were collected through formal interviews and filled the questionnaires.

Price of purchase chicks, cost of labor, cost of feed, feed conversion ratio, mortality percentage, machinery depreciation, electricity, cooling and heating charges, rent and cost of building on the profit of the broiler producer were investigated. Data were evaluated using descriptive and economic technique described by Ajala et al. (2007).

The following profitability measures were calculated.

Profitability Index $=$ Net Farm Income/Gross Revenue

Total Cost $=$ Total Fixed Cost + Total Variable Cost

Rate of Returns on investment \% = (Net Farm Income / Total Cost $) \times 100$

Rate of Return on Variable Cost $\%=($ Total Revenue Total Fixed Cost) / Total Variable Cost $\times 100$

Rate of Return on Fixed Cost $\%=($ Total Revenue - Total Variable Cost) / Total Fixed Cost $\times 100$

Capital Turn Over $=$ Total Revenue $/$ Total Cost

\section{RESULTS}

In the study area average flock size was 29210 birds with an average stocking density of 0.74 square feet and average cost of day old chick amounted to Rs. 45 which accounted $33.30 \%$ of total cost. The average sale price of finished broilers was
Rs. 150/kg. Cost of finisher feed (Rs. 53.50) established the maximum share of the total cost, accounting for $44.10 \%$ while cost of starter feed contributed $10.21 \%$ of total cost. Cost of vaccination and medication was $3.11 \%$ while the cost of labor accounted for $4.00 \%$ of total cost. Further stuffs such as repair cost, fuel, electricity bills, feeders, drinkers and litter cost contributed $<2 \%$ to total cost of production.

Flock size in various broiler enterprises ranged between 20,800 to 38,000 broilers with an average of 29,210 birds (Table 1). The capital investment on environment control houses in the studied samples ranged between Rs. 750,000 to $25,000,000$ with an average investment of $8,347,826$ (Table 1). This variation in investment was due to various customized building styles, designs and even the presence or absence of sensors/environment controllers and variations in electrical controllers and even generators. Equipment used in such houses was mostly automatic feeding and watering lines ranged from locally fabricated to imported solutions from Chinese to European origin. So, the investment on equipment ranged between Rs. 300,000 to 3,000,000 with an average of 2,067,742 (Table 1).

Flock investment included the cost of chicks, feed, vaccination, medication, labour and miscellaneous cost factors like electricity, litter, disinfection etc. flock investment ranged between Rs. 4,900,000 to $15,477,449$ with an average flock expenditure of 6,710,268 (Table 1). Average medicine, vaccination and disinfection costs were Rs. 261,701/-, Rs. 55,970/- and Rs. 40,828/- (Table 1), respectively, there was some limitation in treatment/prevention costs as few farmers recorded all three costs as one and few recorded the medicine/vaccination as single record and few farmers did not recorded the disinfection cost as separate record.

Economic analysis of the data revealed a rate of return on fixed cost of about 430 i.e. for every rupee cost a return of 4.30 rupee was earned by the farmers, similarly a rate of return on variable cost was estimated to be 140 i.e. for every rupee variable cost results in Rs. 1.40 was earned by the

Table 1. Average values of major cost factors in Broiler operations in study area.

\begin{tabular}{lccc}
\hline Particulars & Average & Minimum & Maximum \\
\hline Flock size (No. of birds) & 29210 & 20,800 & 38,000 \\
Length of House & 470.80 & 200 & 600 \\
Width of House & 46.91 & 36 & 100 \\
Stocking Density & 0.74 & 0.64 & 0.86 \\
Day old Chick Price & 45 & 34.50 & 55.50 \\
Finished Broiler Sale Price & 150 & 140 & 157 \\
Building Investment (Rs.) & $8,347,826$ & 750,000 & $25,000,000$ \\
Equipment Investment (Rs.) & $2,067,742$ & 300,000 & $3,000,000$ \\
Flock Investment (Rs.) & $6,710,268$ & $4,900,000$ & $15,477,449$ \\
Medicine Investment (Rs.) & 261,701 & 160,000 & 395,000 \\
Vaccine Investment (Rs.) & 55,970 & 10,000 & 100,000 \\
Disinfectant Investment (Rs.) & 40,828 & 12,000 & 290,000 \\
\hline
\end{tabular}


farmers. Profitability index 00.30 was calculated from the data which means that every 1.00 rupee investment results in 30 paisa profit earned by the farmers during the study period in the study area. Capital turnover of 01.50 indicates that developments in the broiler production is likely to increase the profits to investment of broiler farmers. This showed that to maximize profit from broiler production, all the inputs should be used at their optimum level. For example, more proficient use of feed input can get about increased income recognized from broiler production because it accounts for maximum cost of production. Broiler production is a moneymaking business in the study area. With a Profitability Index (PI) of about 0.30 and Capital Turnover (CTO) of about 1.50 , developments in the broiler production is likely to increase the profits to investment of broiler farmers.

Table 2. Economic analysis of broiler farming in the study area.

\begin{tabular}{lc}
\hline Profitability index (PI) & 00.30 \\
Capital turn over (CTO) & 01.50 \\
Rate of return on investment $(\%)$ & 33.50 \\
Rate of return on variable cost $(\%)$ & 140 \\
Rate of return on fixed cost $(\%)$ & 430 \\
\hline
\end{tabular}

\section{DISCUSSION}

In the study area average flock size was 29210 birds and fixed cost per flock accounted for $15 \%$ while the variable costs per flock accounts for $85 \%$ of total cost of investment. Related results were supported by Rajendran et al. (2008) in India. The total income per broiler bird was Rs. 160 while the total cost earned per bird was Rs.130. Khan et al. (2004) found lesser cost of production and net profit in Chakwal than the current study which suggests that intensely prices has increased. The average net return gained by the studied producers were Rs. 650000 per flock of 30000 birds. Farooq et al. (2001) while studying broiler farmers in Mardan, KPK using similar procedure calculated the net returns to be Rs.79200 flock-1 of 1000 birds. The net return gained by the farmers in the study area was less may be the global business recession and uncontrolled avian influenza H9 attacks resulting in lowered sale prices of broiler meat. The broiler farmers produced income through the sale of live chicken. Income made by the initiative was used back into business for buying feed, medicines, vaccines, etc. therefore making the Capital Turn over (CTO) to be more than 1, suggesting that for every Rupee paid on broiler production about 1.50 Rs. Pay back to the farmer as income. Mohsin et al. (2008) also reported Capital Turn Over of about 1.20 to 1.50 for medium to large size broiler farms in Faisalabad district. The Net farm income (NFI) which characterizes the return to labor and management accounted for Rs.164018, therefore a profit to investment about $33.50 \%$. The profitability index (PI) was 0.30 , showing that for every rupee earned as revenue 30 paisa are repaid to the farmer as net income.

Conclusion: The study concludes that despite numerous highly fluctuating cost factors broiler farming in Pakistan is still a profitable business.

Acknowledgement: The study was conducted under Pakistan Science Foundation's funded project No. PSF/ NSLP/P-AU (167) Entitled "Development of Information Management System for Commercial Broiler and Layer Farm Data”.

\section{REFERENCES}

Ajala, M.K., B.I. Nwagu, A.A. Sekoni and A.O.K. Adesehinwa. 2007. The profitability of turkey production in Zaria, Kaduna State, Nigeria. Asian. J. Info. Tech. 6:27-33.

Ceveger, Y. and C. Yalcin. 2003. A quantitative model to determine factors affecting profits of broiler enterprises. Turk. J. Vet. Anim. Sci. 27:1201-1205.

Farooq, M., M.A. Mian and A. Asghar. 2001. Factors affecting cost of production and net profit per broiler in the subtropics. J. Livest. Res. Rural Dev. Vol. 13. Available online http://www.cipav.org.co/lrrd//rrd13/1/faro131.htm

Government of Pakistan (GOP). 2015-2016. Pakistan Economic Survey. Ministry of Finance, Govt. of Pakistan, Islamabad, Pakistan.

Khan, S., M. Farooq, F.R. Durrani, R. Naveed and H. Khan. 2004. Economic analysis of broiler farms in the arid zone. Sarhad J. Agric. 20:337-341.

Liang, Y., M.T. Kidd, S.E. Watkins and G.T. Tabler. 2013. Effect of commercial broiler house retrofit: A 4-year study of live performance. J. Appl. Poult. Res. 22:211216.

Mohsin, A.Q., R. Riaz, S. Asad and A. Mushtaq. 2008. Profitability analysis of broiler production in Rawalpindi district. Pak. J. Agri. Sci. 45:514-519.

Rajendran, K., B. Mohan, K. Viswanathan and S.C. Edwin. 2008. A study on cost of production of broiler at market age at Palladam area. Tamil Nadu J. Vet. Anim. Sci. 4:6970 .

Samarakoon, S.M.R. and K. Samarasinghe. 2012. Strategies to improve the cost effectiveness of broiler production. Trop. Agric. Res. 23:338- 346.

Zahir-ud-Din, M. Farooq, F.R. Durrani, N. Chand and J. Ahmed. 2005. Status of broilers produced in Swat, Pakistan. Livest. Res. Rural Dev. Vol. 13. Available online at http://www.lrrd.org/lrrd13/3/zahi133.htm 